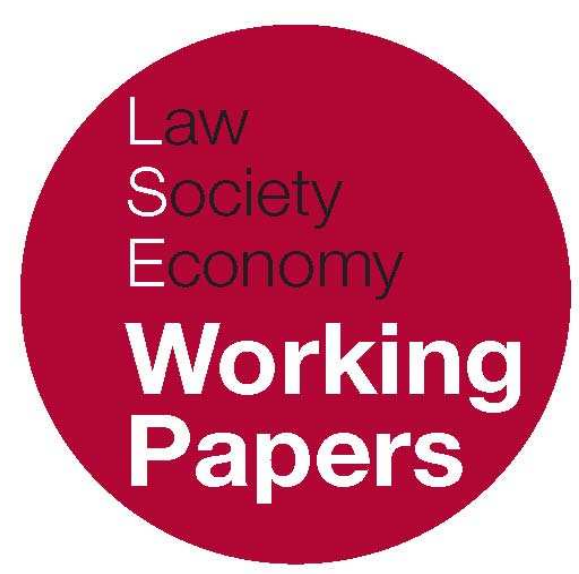

\title{
Between Freedom and Law: \\ Hannah Arendt on the Promise of Modern Revolution and the Burden of 'the Tradition'
}

\author{
Michael A. Wilkinson \\ LSE Law, Society and Economy Working Papers 5/2011 \\ London School of Economics and Political Science \\ Law Department
}

This paper can be downloaded without charge from LSE Law, Society and Economy Working Papers at: www.lse.ac.uk/collections/law/wps/wps.htm and the Social Sciences Research Network electronic library at: http://ssrn.com/abstract=1874741.

(C) Michael A. Wilkinson. Users may download and/or print one copy to facilitate their private study or for non-commercial research. Users may not engage in further distribution of this material or use it for any profit-making activities or any other form of commercial gain. 


\title{
Between Freedom and Law: Hannah Arendt on the Promise of Modern Revolution and the Burden of 'the Tradition'
}

\author{
Michael A. Wilkinson *
}

\begin{abstract}
What are the juridical implications of Hannah Arendt's conception of freedom as political rather than personal, based on action in the circumstances of plurality rather than an absence of interference in the context of isolated contemplation? This is not a question of mere philosophical speculation. According to Arendt, the experience of modern revolution, beginning in America and France at the end of the 18th century, marks the appearance of freedom as a worldly, political phenomenon with the potential to change our understanding of the constitutional foundations of authority. And yet this potential is betrayed due to the inability of our juridical imagination to escape two conceptual dead-ends: the image of law as command and the model of constitutionalism as a process of fabrication, both of which, in different ways, suppress our sense of political freedom by expressing constitutional foundations in terms of sovereign 'absolutes'. In so doing the modern juridical imagination neglects the significance of two older conceptions of law, the Greek nomos and the Roman lex, neither of which depend upon such absolutist foundations. The Roman lex might suggest a way out of this conceptual impasse, by conceiving law as relational, dynamic, and intertwined with the political at its root, but in a manner captured by the metaphor of constitutionalism as 'political grammar' or 'syntax'.
\end{abstract}

\footnotetext{
* London School of Economics and Political Science. A revised version of this essay is forthcoming in M. Goldoni and C. McCorkindale (eds), Hannah Arendt and the Law (Oxford: Hart Publishing, 2011). Earlier versions were presented at Antwerp University and Tilburg University. I would like to thank Chris MacCorkindale and Marco Goldoni for inviting me to take part in their project, the participants in both conferences for valuable discussion, and Martin Loughlin for comments on an earlier draft.
} 


\section{INTRODUCTION}

In principle, all modern constitutions begin with 'We the People'.1

From Arendt's reflections on modernity an ambiguous account of the relationship between freedom and modern law emerges. On the one hand, the revolutionary events in America and France in the late eighteenth century mark the appearance of a strong sense of 'political freedom' in the world, with the novelty that subjects now consider themselves rulers. 'We, the people' are the new foundations of political and constitutional authority. We become aware of our constitutional potentia, the power to authorise new institutions and new basic laws; in Habermasian terminology, the modern state is marked by the idea that subjects are citizens, not merely the 'addressees' of law but also its 'co-authors'. Exemplified in those modern revolutionary moments on either side of the Atlantic, Arendt suggests, is a radical sense of freedom as collective action in the circumstances of plurality. This signals a break with 'the great tradition's of philosophy that had prioritised isolated contemplation over the plurality of politics and divorced freedom from the experience of action. And since our conception of law is a reflection of our self-understanding as social and political animals, ${ }^{4}$ the new sense of political freedom that emerges with the birth of our constitutional potentia also implies a shift in the modern juridical consciousness. ${ }^{5}$

And yet, from the outset, two features of this juridical consciousness, which survive and are even reinforced by modern revolution, undermine our constitutional potentia. First, there is the puzzling persistence of a traditional conception of law as command, which assumes rulers and ruled, sovereign and subject, and an 'absolute' source of law's authority (whether 'nature's God', the 'sovereign nation', or 'self-evident truths'). Second, modern constitutionalism suggests the priority of fabrication (in the guise of constitution-making) over action (or constitutional politics), a hierarchy that was implicitly set in motion by the Platonic inauguration of 'the tradition'. 6 Although the 'imperative' conception of law combined with the turn to constitution 'making' or 'fabrication' are not solely

\footnotetext{
${ }^{1}$ S. Chambers, 'Democracy, Popular Sovereignty and Constitutional Legitimacy' (2004) 11 Constellations 153-173, 153.

${ }^{2}$ H. Arendt, On Revolution (London: Penguin, 1963), 31.

${ }^{3}$ For Arendt, the 'tradition', or what she sometimes calls the 'great tradition', of political philosophy begins with Plato and ends with Marx. See H. Arendt, Between Past and Future (New York: Penguin, 1968), 17.

${ }^{4}$ According to Joseph Raz, '[W] hat we study when we study the nature of law is the nature of our own self-understanding [...] It is part of the self-consciousness of our society to see certain institutions as legal.' See 'Can There be a Theory of Law' in Between Authority and Interpretation (Oxford: OUP, 2010), 31. And we might add, as this self-consciousness changes, so does our conception of the nature of law, even if, as Raz argues, the nature of law itself cannot change.

5 I use the term 'constitutional potentia' in the sense of a 'power to' constitute and reconstitute basic laws, or 'political right', as Martin Loughlin puts it. See eg M. Loughlin, Foundations of Public Law (Oxford: OUP, 2010), 11-12.

${ }^{6}$ Fabrication, corresponding to 'work', is one of the three aspects of the vita activa in Arendt's account of the human condition, alongside 'action' and 'labour'.
} 
responsible for the eventual loss of the revolutionary treasure, the decline of the public realm, and the eclipse of political freedom that Arendt traces in late modernity, ${ }^{7}$ they do represent for Arendt the hallmarks of an escape from politics and therefore from freedom itself.

At the heart of modern constitutionalism lies this fateful ambivalence between the promise and collective self-consciousness of political freedom, which suggests an escape from 'the tradition', and an ideology of sovereignty and constitution-making that not only remains bound to 'the tradition' but also liberates it from its ancient and yet insincere prejudices against the category of 'fabrication'. This dilemma cannot be easily resolved because Arendt does not confront head-on the tension between political freedom and law or make any systematic attempt to uncover or develop an alternative conception of law 'beyond the tradition'. The purpose of this essay is to explore this tension more systematically, by drawing together Arendt's scattered remarks on the tension between freedom and law as it appears in the modern imagination and by developing her suggestion that a turn to earlier conceptions of law based on nomos and lex might have alleviated it.

After presenting Arendt's critique of the traditional understanding of freedom, and exploring her suggestion that the revolutionary events demonstrate the possibility of a genuine alternative, we examine how the tradition not only maintained its grip on the juridical consciousness in the guise of sovereign command but was actually strengthened and even 'liberated' by the modern substitution of fabrication for action. Two alternatives to the traditional imperative conception of law are then examined, the Roman lex and Greek nomos. Although both avoid the appeal to the 'absolute' associated with that tradition, only the image of law as lex challenges the priority of fabrication over action. By way of conclusion, a final tension that remains unresolved in the Arendtian framework is introduced, the tension between democratic freedom and constitutional authority. Put simply, how can the constitutional authority of the few be reconciled with the political freedom of the many? It will be argued that the image of law as lex might begin to suggest a way out of this conceptual impasse, by conceiving law as relational, dynamic, and intertwined with the political at its root, but in a manner captured by the metaphor of constitutionalism as 'political grammar' or 'syntax'.

\footnotetext{
7 To explain fully the eclipse of political freedom and our modern 'world alienation' would require exploration of the late modern domination of the socio-economic sphere, the rise of instrumental rationality, and the logic of functionalism and 'process', culminating in the total exclusion of the public realm in twentieth century totalitarianism. This essay only deals with the early modern substitution of action in favour of fabrication and not the late modern elevation of labour over fabrication. For a thorough examination of these two reversals that Arendt identifies, see M.P. D'Entreves, The Political Philosophy of Hannah Arendt (London: Routledge, 1994).
} 


\section{CRITIQUE OF THE TRADITION: ARENDT'S CONCEPTION OF POLITICAL FREEDOM}

Although Arendt's work is sometimes credited with contributing to the prominence of 'positive freedom' in the lexicon of contemporary political philosophy, without further qualification this would be a quite misleading claim. ${ }^{8}$ Arendt revitalises the concept of freedom in a unique manner, forging an intimate connection between freedom and the 'political' by recovering the Aristotelian category of praxis and by invoking those historical moments since the French and American revolutions when freedom has made its appearance in the world. And, most radically of all, not only does she disparage the modern liberal tradition for its role in the demise of political freedom; she extends the roots of its decline back to the Platonic turn which, in announcing the philosopher's claim to rule, announces the priority of philosophy over politics and the safety of the philosopher over the action of the citizen. ${ }^{9}$

To recover the sense of freedom in praxis - freedom to rather than freedom from - is to recover the activity and experience of politics. This in turn is essential in order to come to grips with that aspect of the human condition that makes politics fundamental, namely plurality, the fact that men, and not Man, live on the earth and inhabit the world. ${ }^{10}$ As Arendt so forcefully puts it at the outset of the Human Condition, 'plurality is specifically the condition - not only the condition sine qua non but the condition per quam - of all political life'.11 Urging the recovery of political freedom is not only a reaction to the rise of homo faber and then of animal laborans in the modern age, to the retreat away from political action into the fields of science and economics and the functionalism and instrumentalism of human activity that this retreat entails, but a response to older, related, but more deeply engrained, facets of our loss of freedom.

It is a response first to the Platonic turn towards isolated contemplation, the retreat from politics into philosophy represented allegorically in the parable of the cave that begins the 'great tradition' with the philosopher seeking to escape from the darkness of the cave and the shadowy company of his fellow men to find an ideal truth in solitude. It is a response, secondly, to the Christian-theological turn inwards, epitomised by the Calvinist doctrine of internal salvation, which suggests that one can suffer from total 'unfreedom' in the 'external world', and yet still be free. Freedom, on the contrary, must enjoy a worldly reality and be meaningfully experienced in action. This is no mere idealistic pipe dream for Arendt; action is at

\footnotetext{
8 Arendt's understanding of freedom is not, as sometimes suggested, simply a reflection of positive as opposed to negative liberty in the sense described by Isaiah Berlin in his celebrated essay. For this reason, I use the term 'political freedom' rather than 'positive freedom'.

${ }_{9}^{9}$ Arendt, $\mathrm{n} 3$ above, 107.

${ }^{10}$ H. Arendt, The Human Condition (Chicago: University of Chicago, 1958), 7. As Jerome Kohn puts it in the introduction to Between Past and Future, n 3 above, plurality, action, and politics are Arendt's 'trinity'. xiv.

11 Arendt, ibid, 7. See also H. Arendt, The Promise of Politics (New York: Schoken, 2005), 93-95.
} 
the foundation of the human condition. It is the most significant, because most distinctively human, aspect of the vita activa.

The great tradition of philosophy as well as the entire impulse of the modern age is criticised as, in Arendt's words, a 'conscious attempt to divorce the notion of freedom from politics,' and thereby 'to arrive at a formulation through which one may be a slave in the world and still be free'.12 Socratic philosophy and Christian theology begin this divorce by elevating above all else the vita contemplativa, the outstanding characteristic of which is described by analogy to the 'motionlessness' with which the inner eye 'sees the shape of the model according to which [the craftsman] fabricates his object'. ${ }^{13}$ The modern liberal tradition continues to pursue this divorce by explicitly undermining action and it is only accelerated with the subsequent Marxian emphasis on labour (the second reversal in the hierarchy) ${ }^{14}$ and Engel's transformation of politics into the 'administration of things' that prefigures modern totalitarianism. ${ }^{15}$

Freedom in the modern liberal tradition is construed in Hobbesian terms as both material and personal. Based on the principle of 'non-interference', it is secured through a rational-legal framework in which the State exists only to protect individual interests. Over time this mutates into an obsession with aggregate welfare (economic 'growth'), reflects the dominance of an instrumental rationality and ultimately succumbs to the 'iron cage' of bureaucracy. Political action, replaced first by bomo faber in the early modern condition is ultimately displaced by animal labourans, leading to modern 'world alienation' with the rise of a social sphere characterised by transience and anonymity. Only foreign affairs, because not (yet) reduced to economic factors, 'seems to be left as a purely political domain'. ${ }^{16}$ The modernist worldview thus considers politics to be 'concerned almost exclusively with the maintenance of life and the safeguarding of its interests'. ${ }^{17}$ For Arendt, on the contrary, politics is about more than 'mere life' and 'personal interests'; it is about the world, which means a public realm that outlasts each and every individual. ${ }^{18}$

Arendt traces the fate of an alternative and authentic conception of freedom as part of the vita activa, from the pre-Socratic Greeks, through its demise as a result of the 'Christian suspicion' of and hostility to the public realm (particularly in Protestant salvation), to our distrust of it in the wake of the experiences of

\footnotetext{
12 Arendt, $\mathrm{n} 3$ above, 146.

13 Arendt, n 10 above, 302.

14 See note 6 , above.

${ }^{15}$ See Arendt, $\mathrm{n} 3$ above, 19. The point is made as strongly in The Human Condition, n 10 above: 'Escape from the frailty of human affairs into the solidity of quiet and order,' Arendt notes, 'has in fact so much to recommend it that the greater part of political philosophy since Plato could easily be interpreted as various attempts to find theoretical foundations and practical ways for an escape from politics altogether'. 222.

16 Arendt, $\mathrm{n} 3$ above, 154. See also Arendt, n 2 above, 77, viewing this as a result of Rousseau's sovereign will and its sense of national unity or the unity of the 'social'.

17 Arendt, $\mathrm{n} 3$ above, 154.

18 'Courage is indispensable' for this public realm, Arendt urges, 'because in politics not life but the world is at stake' (ibid, 155).
} 
modern totalitarianism in the 20th century. The experience of totalitarianism seems to suggest no more than the canon of modern political theory had already led us towards, namely the conclusion that freedom is assured by guaranteeing a sphere of personal liberty rather than jointly exercised in the creation and maintenance of spaces for political action.

In the urge to rescue politics from philosophy by recovering a conception of political freedom, Arendt therefore takes aim at the entire Western tradition. The category of freedom has been lost to us because the tradition prioritised a dialogue with the self (the 'dialogue' between 'me and myself' in the course of contemplation) over the dialogue with others (participation and speech in the course of action). The first 'dialogue', the inward experience of freedom, in as much as its significance cannot be denied, is derivative. It is only in the second dialogue, which comprises the field of human affairs and politics, that freedom can properly be recovered:

[A]ction and politics, among all the capabilities and potentialities of human life, are the only things of which we could not even conceive without at least assuming that freedom exists, and we can hardly touch a single political issue without, implicitly or explicitly, touching upon an issue of man's liberty [...] The raison d'être of politics is freedom, and its field of experience is action. ${ }^{19}$

Freedom, for Arendt, is emphatically not a phenomenon of the 'will', a question of one's personal freedom to choose from a set of already existing alternatives, ' $x, y$ or z'. It is not about being able to manage our own strategic choices, selecting the most efficient means to ends that are predetermined. It is not even about being able to choose our ultimate goals or the absence of interference (or domination) by others in this choice and the means to pursue it. It is the freedom to 'call something into being which did not exist before', something that is not given 'even as an object of cognition'. 20 This conception of freedom, which depends upon man's faculty to begin something new, reflects the centrality of the event of 'natality' for the human condition. 'The new beginning inherent in birth,' Arendt notes, 'can make itself felt in the world only because the newcomer possesses the capacity of beginning something anew, that is, of acting,' and in so doing of performing the unexpected and even the 'infinitely improbable'. ${ }^{21}$ It is only in the course of acting and speaking in the public realm that men reveal this potential to

\footnotetext{
19 ibid, 145.

20 ibid, 150.

${ }^{21}$ Arendt, n 10 above, 9, 178. Natality, she adds, 'may be the central category of [...] political thought [...] Of the three aspects of the vita activa, action has the closest connection with the human condition of natality'.
} 
the world by revealing who they are, exercising their freedom by disclosing their 'unique personal identities'. 22

Political freedom, which must transcend both our motives and our intended goals, is not, as the analogy with the unexpected might suggest, wholly arbitrary. ${ }^{23}$ It springs from what Arendt somewhat enigmatically calls 'principle', and as she will later note in reference to the new beginning that is the American revolution, 'beginning' and 'principle' have the same etymological root. Principle, in contrast to the judgment of the intellect and to the command of the will, is fully manifested only in action itself. But whatever the nature of the principle that inspires action whether it is the love of equality, which Montesquieu called virtue, or fear and distrust - it is only in action that men can experience freedom and only through action with others that political power is generated. ${ }^{24}$

This experience of action in the public realm, whether it is the creation and maintenance of political and social institutions or the promises that men make to each other in their daily lives, has no independent life outside of the continued conservation of those institutions or promises by those through whose action they were constituted and might be maintained.25 Although it is, to be sure, both unpredictable in nature and fragile in its existence, the idea of political freedom, which can be resurrected from our neglected traditions and historical experiences, still looms large in our imagination. Despite the apparent triumph of modern liberalism and the fear of any alternatives inculcated by the experience of totalitarianism in the 20th century, we still hold out for this more demanding sense of freedom and the juridical consciousness that accompanies it. If the culmination of the great tradition of philosophy is the suggestion that freedom is only experienced in isolated contemplation or the pursuit of individual interests, then the episodes of modern revolution call into question such received wisdom as well as the traditional understanding of law which accompanies it.

\section{ESCAPE FROM THE TRADITION: POLITICAL FREEDOM IN THE MODERN REVOLUTIONARY IMAGINATION}

The modern conception of revolution, inextricably bound up with the notion that the course of history suddenly begins anew, that an entirely

\footnotetext{
$22 \mathrm{ibid}, 179$. 'It is in the nature of beginning that something new is started which cannot be expected from whatever may have happened before. This character of startling unexpectedness is inherent in all beginnings and in all origins [...] The fact that man is capable of action means that the unexpected can be expected from him, that he is able to perform what is infinitely improbable'. ibid, 177-178.

23 Arendt stresses that she is not suggesting the rightness or wrongness of our goals are unimportant only that such questions are ones of judgment, which precedes the will, and not of freedom.

24 Arendt, n 3 above, 151.

25 The analogy apposite to the exercise of political freedom is not the activity of work and the product of making, eg of a work of art, or a novel, but of spontaneous and improvised performance in concert with others, expressed in word and deed and arising 'in between' men. ibid, 153.
} 
new story, a story never known or told before, is about to unfold, was unknown prior to the two great revolutions at the end of the eighteenth century. 26

The French and American revolutions bring us closer to this conception of political freedom as it makes its appearance (or reappearance) ${ }^{27}$ in the world and in doing so reveal its implications for our juridical consciousness. But it bears reiteration that the period from the late eighteenth century up to the middle of the 'American century' in which Arendt was writing are those of the triumph of a liberal worldview in which 'negative liberty' looms large, and 'political freedom' has largely disappeared. These revolutionary events that Arendt recovers therefore present us with something of the exceptional. ${ }^{28}$ And yet although political freedom as experienced in the course of modern revolutions is in tension with the liberal tradition as well as the Christian tradition and the great tradition of Philosophy which preceded it, ${ }^{29}$ at the same time it appears (in hindsight) to be an inevitable part of our modern juridical consciousness manifested most apparently in the concept of constituent power: 'we, the people' are the foundations of the modern constitutional settlement. The recovery of political freedom therefore trades both on the exceptionality of the revolutionary moment and on its unavoidability in hindsight; it remains with us in the way we conceive of constitutionalism in modernity - namely in accordance with an ideology of popular sovereignty, irrespective of the extent to which it is fulfilled or betrayed in practice.

'Crucial to any understanding of revolutions in the modern age,' Arendt suggests, 'is that the idea of freedom and the experience of a new beginning should coincide. ${ }^{30}$ Unique about modern revolution is that freedom is conceived not as a mental category of thought, judgment, and will, but as a category of action and, furthermore, in a manner that supersedes the weak sense of mere 'liberation' from the oppression of the ancien régime and the constraints of the traditions that it embodied. It emerges in the strong sense of revealing our constitutional potentia, the capacity to create a 'new beginning' for political freedom, as well as institutions to preserve a space in which freedom can be exercised for posterity (freedom as the experience of the 'We can' rather than the 'I will'). ${ }^{31}$ Of the self-conception of the American founders, the record of the American Revolution speaks an entirely

\footnotetext{
26 Arendt, n 2 above, 28.

${ }^{27}$ Little here turns on whether the break itself is absolute, in the sense of utterly unprecedented. Arendt elsewhere suggests the revolutionaries are attempting to recover something lost: See $\mathrm{n} 3$ above, 140.

${ }^{28}$ This is sometimes missed when focusing on the text of On Revolution, Arendt, n 2 above. Arendt's pessimism is presented more starkly in The Human Condition, n 10 above, and The Origins of Totalitarianism (USA: Harcourt, Inc., 1966).

${ }^{29}$ Arendt argues that the Christian rejection of politics is even more radical than the Platonic one because the idea of a public space is intolerable in Christianity. n 11 above, 135-138.

30 Arendt, n 2 above, 29.

31 Arendt contrasts freedom as the 'I will' with the freedom as the 'I can'. n 3 above, 157-161. But since political freedom is experienced in concert with others, the notion of the 'We can' presents a more apposite contrast.
} 
clear, unambiguous language: it was not constitutionalism in the sense of 'limited', lawful government that preoccupied their minds. ${ }^{22}$ The main question for them, 'was not how to limit power but how to establish it, not how to limit government but how to found a new one'. 33

Freedom needed, in addition to mere liberation, the company of other men who were in the same state, and it needed a common public space to meet them - a politically organised world, in other words, into which each of the free men could insert himself by word and deed. ${ }^{34}$

To capture the modernity of revolution is to capture the sense that more than merely liberation (from monarchy, despotism, or oppression) is at stake, which generally trades on a negative conception of liberty as freedom from interference or domination. The constitution of political freedom is at stake, and this requires the establishment of political equality among citizens in a republic who are responsible for their own laws. In other words, it is about experiencing and constituting the freedom to govern in concert with others rather than the freedom from oppressive government by those in power. The revolutions thereby arouse passions that have been dormant for man outside of classical antiquity, absent in the centuries between the fall of the Roman Empire and the beginning of the modern age. Of the sheer extraordinariness of this experience, the startling recognition of man's capacity for beginning anew, Arendt is in little doubt. It is at the root of the enormous pathos we find in both the American and the French 'revolutionary spirit', a spirit which consists, she says, in 'the eagerness to liberate and to build a new house where freedom can dwell', and is 'unprecedented and unequalled in all prior history'. ${ }^{35}$

The event of modern revolution connects political freedom to a legaltheoretical enquiry with the emergence of this constitutional potentia, an idea with real juridical significance because it suggests the ultimate foundations of constitutional authority lie with the collective power of the people to constitute their own basic laws. From a juridical perspective, whilst the original political meaning of the revolutions, was, as Arendt explains, that of demanding a return to the limited government of the past - the restoration of ancient liberties that had been slowly eroded by the monarchies in England and France - the outcome was far more radical, leading spectacularly to a whole new social imaginary, based on constituent power and popular sovereignty. ${ }^{36}$

It is not only that limiting government - in terms of securing guarantees against it, such as those found in a Bill of Rights, including rights of representation

\footnotetext{
32 Arendt, n 2 above, 147.

33 ibid, 148.

34 Arendt, $n 3$ above, 147.

35 Arendt, n 2 above, 35. Italics added. But see n 28 above.

36 On popular sovereignty as an aspect of the modern social imaginary, see C. Taylor, Modern Social Imaginaries (Durham: Duke University Press, 2004).
} 
and voting - was historically nothing new; it is that such a conception of the constitution suggests political freedom is about procuring safeguards against government, when in truth it is about claiming a share in government. ${ }^{37}$ The difference is captured in the observation that although the idea had already developed that the people might rebel against a particularly despotic ruler, there was simply no way of describing 'a change so radical that subjects became rulers themselves. 38

The turn towards understanding the constitution as an act of collective lawmaking rather than merely of liberation from the tyrannical laws made by others is irrevocably tied to the period of modern revolution. Wherever we locate the beginning of modern political thought, with Locke or Hobbes, Bodin or Machiavelli, the awareness that a new beginning could actually occur in historical time as a political phenomenon, that it could be, in Arendt's words, 'the result of what men had done and what they could consciously set out to do', emerges only in the course of the late eighteenth century revolutions. ${ }^{39}$ Figures in the great tradition such as Hobbes and Locke might have been revolutionary theorists, in the sense of questioning dogmatic assumptions about the nature of authority and the activity of political philosophy, but they were emphatically not theorists of revolution. The strange pathos of novelty, 'so characteristic of the modern age', Arendt remarks, 'needed almost two hundred years to leave the relative seclusion of scientific and philosophic thought and to reach the realm of politics'. 40

To be sure, we could view the revolutionary practice of the late 18th century as presenting less of a radical break and more of a continuity with the earlier 17th century ideas of social contract, which liberated political philosophy from its theological straightjacket in its search for scientific or quasi-scientific foundations for authority. ${ }^{41}$ In the process of historical excavation, we could aim our sights back further still in the search for the decisive break from the traditionalism of the Middle Ages. According to Herman Heller, the 'immanence conception' of a pouvoir constituant that is actually capable of action, 'which no longer shares the belief in the politically constitutive power of a transcendent God, but believes only

\footnotetext{
37 Arendt, $\mathrm{n} 2$ above, 143. As Arendt puts it, if no more had ever been at stake in the revolutions than this kind of constitutionalism, ['the liberties which the laws of constitutional government guarantee and are all of a negative character' ibid], it would be as though the revolutions has remained true to their modest beginnings when they could be understood as attempts at restoration of ancient liberties: the truth of the matter, however, is that this was not the case'. ibid, 143-144.

38 ibid, 41. A constitution, in Paine's terms, is the act of a people constituting a government, not the act of government itself. Quoted by Arendt herself, ibid, 145.

39 ibid, 46.

40 ibid.

${ }^{41}$ Hobbes had compared his endeavour to Euclidian geometry. In the words of Ernst Cassirer, 'the American Declaration of Independence had been preceded by an even greater event: by the intellectual Declarations that we find in the theoreticians of the seventeenth century.' It was there that 'reason had first declared its power [...] its claim to rule the social life of man [and] emancipated itself from the guardianship of theological thought'. In E. Cassirer, The Myth of the State (New Haven: Yale University Press, 1946), 167.
} 
in the populas, the universitas civium' emerges as early as Marsilius of Padua in the late Middle Ages. ${ }^{42}$

But intellectual history is not our prime concern. It is only when the phenomenon of revolution makes its actual appearance in the world that newness is no longer considered merely the 'gift of Providence' but is 'endowed with a reality peculiar to the political realm'. ${ }^{43}$ The historical examples of revolution - whether it is the American or the French, the later experience of the Paris Commune of 1871, the creation of Soviets during the Russian revolution, the French Resistance during World War II, or the Hungarian revolt in 1956 - show that individual men and women could 'step forward from their private lives in order to create a public space where freedom could appear'. In doing so, it is claimed, 'they rediscovered the truth known to the ancient Greeks that action is the supreme blessing of human life'. ${ }^{44}$ 'Only in such revolutions', Arendt notes, 'was there a direct link between the idea of participating in government and the idea of being free." 45

Once political action is perceived as a phenomenon capable of jurisgenesis or what might be called constitutio-genesis, the foundations of an immanent and mundane 'authorising authority' are firmly laid; our constitutional potentia is laid bare. The Arendtian notion of potentia is conceived 'neither as a potential for asserting one's own interests or for realizing collective goals, nor as the administrative power to implement collectively binding decisions, but rather as an authorising force expressed in "jurisgenesis" - the creation of legitimate law - and in the founding of institutions'. ${ }^{46}$ Since power for Arendt, unlike violence, is always the power to act in concert with others, potentia is an inherently collective notion. Never 'the property of an individual' or merely instrumental to another goal, political power necessarily 'belongs to a group and remains in existence only so long as the group keeps together'. ${ }^{7}$

The revolutionary notion of a 'new constitutional beginning' is, however indirectly, a juridical phenomenon because it expresses the idea that ultimately we are the authors of our own laws. Habermas will later develop this insight into a fully-fledged discourse theory of law and democracy. But for Arendt, and not for Habermas, this promise of political freedom, which can be glimpsed in those moments of revolutionary action, is ultimately betrayed in the course of the modern age. 48 We need not get embroiled in the more general pathologies of modernity, however, because Arendt presents us with one quite straightforward and immediate reason for the failure of the constitutional potentia, namely the

\footnotetext{
${ }^{42}$ H. Heller, Staatslebre, D. Dyzenhaus (trans) (1996) 3 Cardozo Law Review 1139, 1215.

${ }^{43}$ Arendt, $\mathrm{n} 2$ above, 46.

${ }^{44}$ D'Entreves, $\mathrm{n} 7$ above, 68.

45 Arendt, The Promise of Politics, $\mathrm{n} 11$ above, 142-143.

46 J. Habermas, Between Facts and Norms (Cambridge Mass.: MIT, 1996), 148. He continues: 'It manifests itself $[\ldots]$ above all in the freedom-founding acts that bring new institutions and laws "into existence"". 148.

${ }^{47}$ H. Arendt, On Violence (New York: Harcourt, 1969), 44.

48 Habermas's re-appropriation of 'communicative power' attempts to overcome the deeply pessimistic tone in Arendt's assessment that praxis has been undermined, first by homo faber, and then by animal labourans in the course of the modern age.
} 
persistence of the 'absolute' in our juridical imagination, due to the perceived need for extra-human foundations to serve as a guarantee for the new constitutional settlement. This need for an absolute is reflected in two ways: the persistence of a traditional conception of law as command and an image of the constitution as a fabricated object. From this perspective, the idea of a revolutionary 'new beginning' presents less of a novel and tremendous possibility, than a familiar and perplexing problem, ${ }^{49}$ to square the circle of legitimacy of the new power and the legality of the new laws. In the realm of ideas, and in particular those which inform our conceptions of law, the revolutionaries on both sides of the Atlantic remained tied to the juridical tradition of the past and to the political 'unfreedom' that it entailed. It is the purpose of the next part to explain how.

\section{THE BURDEN OF 'THE TRADITION': THE PERSISTENCE OF THE ABSOLUTE IN THE JURIDICAL IMAGINATION}

Commentators frequently criticise Arendt for unduly favouring the US revolutionary tradition over its French counterpart, for exaggerating in her praise of the 'political' revolution in the New World and in her condemnation of the 'social' revolution in the Old. ${ }^{50}$ The relative success of the US revolution is partly reduced by Arendt to a simple comparison of material conditions, the blunt fact, as she saw it, that 'the predicament of poverty was absent from the American scene'. ${ }^{51}$ Arendt's claim that political freedom is undermined if contaminated by the social question has received a great deal of criticism, ${ }^{52}$ but it can be bracketed here, because in juridical terms the burden of the tradition weighs as heavily on both revolutionary experiences. This similarity between the New and Old world revolutions is often overlooked in the push to highlight their differences, which were not only material. Thus in historical terms, whereas the French revolution took place against a backdrop of monarchical absolutism, the American revolutionaries already had the experience of limited government - the constitutionally limited king of the English constitution - on which to draw. Quite simply, as Arendt put it, 'the more absolute the ruler, the more absolute the

\footnotetext{
49 The modern revolutions, Arendt clarifies, are 'the only political events which confront us directly and inevitably with the problem of beginning'. n 2 above, 21.

50 See eg W.E. Scheuerman 'Revolutions and Constitutions: Hannah Arendt's Challenge to Carl Schmitt' (1997) Canadian Journal of Law and Jurisprudence 141. Arendt herself says that 'nothing could be less fair than to take the success of the American Revolution for granted and to sit in judgment over the failure of the men of the French Revolution'. n 2 above, 68.

51 Arendt, ibid, 68.

52 For an outstanding example, see S. Wolin, 'Democracy and the Political' in L.P. Hinchman and S.K. Hinchman (eds), Hannah Arendt: Critical Essays (New York: SUNY, 1994), 289, focusing on the absence of any sustained reflection on social power and social justice in Arendt's work.
} 
revolution will be which replaces him'. ${ }^{53}$ The men of the US revolution avoided the pitfalls not only of an essentialist nationalism, but also of any assumption that power and law are unitary, stemming from a single indivisible source, which was the 'fateful blunder of the men of the French revolution'. ${ }^{54}$ The source of power and authority were institutionally separated from the outset in the US, with power vested in 'the people' and authority embodied in the constitution and exercised for posterity by the Supreme Court and the Senate. .55

In contrast to the disorganised yet relatively homogenous multitude in France, the US already enjoyed constituted yet diverse pouvoirs constituants in the form of the self-governing bodies that preceded the Federal Constitution. Because the Declaration of Independence followed constitution-making in all of the thirteen colonies, the doctrine of popular sovereignty could emerge without 'unleashing the boundless violence of the multitudes'. ${ }^{56}$ The phenomenon of political action, as well as the distinction between power and violence, was already known to the Founders. ${ }^{57}$ The social contract had actually been practised at a horizontal level in the form of real covenants, alliances, and mutual promises (such as the Mayflower pacts) rather than merely theorised hypothetically as the bierarcbical surrender to a Hobbesian Leviathan.

And yet although the American Revolution represents a certain success relative to the French, Arendt laments its 'loss of the revolutionary treasure', the failure to institutionalise political freedom, so that, in conformity with Jefferson's wishes, each generation might enjoy the exhilarating experience of founding anew the constitution. Blighting the efforts of the founders from the outset - despite their having almost miraculously stumbled upon a way out of the revolutionary impasse and of avoiding the dangers of absolutism that so beset the French - was a failure of the juridical imagination common to both revolutionary traditions and of a different order than any material or institutional contrasts would suggest. So even the American revolution, which was not burdened either with political or nationalistic absolutism, or with desperate poverty, still was burdened by the philosophical-political need for an absolute; it 'still occurred within a tradition that was partly founded on an event in which the "word had become flesh", that is, on an absolute that had appeared in historical time as a mundane reality'. ${ }^{58}$ That the need for a transcendent, transmundane source of religious or quasi-religious sanction to ground the new constitutional foundation persisted in the US showed that 'the problem of an absolute is bound to appear in a revolution'. Indeed, that such is the case, 'we might never have known without the American revolution', since in other respects it distinguished itself so clearly from the predicament of the Old World.

\footnotetext{
${ }^{53}$ Arendt, $\mathrm{n} 2$ above, 155.

$54 \mathrm{ibid}, 165$.

55 The Supreme Court, Arendt notes, citing Woodrow Wilson, exists as a kind of 'Constitutional Assembly in continuous session'. ibid, 200.

$56 \mathrm{ibid}, 166,182$.

57 ibid, 181

58 ibid, 160 .
} 
The revolutions on both sides of the Atlantic faced the task of establishing a new authority, 'unaided by custom and precedent and the halo of immemorial time'. ${ }^{59}$ The absolute was thus invoked to break the two 'vicious circles' of the legality of the new source of law, and the legitimacy of the new source of power. Sieyes 'solved' this problem by drawing his famous distinction between pouvoir constituant and pouvoir constitué, placing the pouvoir constituant in a perpetual state of nature and anchoring power and law in the will of the nation, 'which remained outside and above all government and all laws'.60

But substituting natural law with the mythical will of the nation, which for Arendt is 'the cheapest and most dangerous disguise the absolute ever assumed in the political realm', was no genuine solution at all to the vexed problem of foundations. Besides the nation being a 'dangerous' and 'cheap' substitute for popular sovereignty (rather than a genuine expression thereof), there is a problem of future stability for the new republic. Since the will of the 'multitude' is transient almost by definition, 'a structure built on it as its foundation is built on quicksand'. ${ }^{61}$ This state of endless fluidity enabled the authoritarian manipulation of the idea of the national will, leading to Napoleon Bonaparte being able to declare: 'Je suis le pouvoir constituant' So the appeal to a quasi-metaphysical nationalism seems to be caught between two poles: it is inauthentic and imposed from the top-down (an 'invented' tradition), or it is a genuine reflection of the political and social reality on the ground, but, and therefore, it is inherently unstable.

The US was not ready to 'invent' its nationalism, and it thus avoided that particular temptation that beset the French. And yet despite having serendipitously stumbled upon the path to avoiding 'the absolute' - the very act of founding itself - the Americans ultimately failed, like their French counterparts, to preserve the new constitutional potentia. According to Arendt, we cannot divorce this failure from the problem of 'the absolute', which persisted due to the second vicious circle of the legality of the new laws of the republic. The New World revolutionaries remained plagued by the need for a ground for law that would serve as an authority for the new constitution, the need, as it might be described, for an 'Immortal Legislator'.

[T] he very task of laying down a new law of the land, which was to incorporate for future generations the "higher law" that bestows validity on all man-made laws, brought to the fore, in America no less than France, the need for an absolute. ${ }^{62}$

\footnotetext{
59 ibid, 160.

$60 \mathrm{ibid}, 163$. As Sieyes puts it in his revolutionary pamphlet, 'What is the Third Estate?', 'the nation is prior to everything. It is the source of everything. Its will is always legal; indeed it is the law itself. In E. Sieyes, Political Writings, M. Sonenscher (trans) (Indianapolis: Hacket Pub. Co., 2003), 136.

61 Arendt, n 2 above, 163.

62 ibid, 182.
} 
Although this problem did not lead the men of the American Revolution 'into the same absurdities' as it did the French, it nevertheless betrayed the promise of political freedom. In the American no less than the French revolutionary mind, to square the circle of the legality of the new laws, to put the 'law above men', as Rousseau puts it, il faudrait des Dieux. ${ }^{33}$ That the need to base their claims on foundations external to and independent of mere assertion or opinion continued to haunt the men of the American Revolution and infect their own ideas is evidenced by their appeal to 'self-evident' truths in the Declaration, an alternative, but equally ideological, absolute to Divine Right. The declaration that 'we hold these truths to be self-evident', combines the relative, 'an agreement between those who have embarked on revolution' and the absolute, 'a truth that needs no agreement since, because of its self-evidence, it compels without argumentative demonstration of political persuasion'. ${ }^{64}$

This need for absolute foundations for basic laws infected the Enlightenment mind more generally, whether in the form of Rousseau's theological lament or Kant's sardonic quips that man is an 'animal that needs a master' and that one 'ought to obey God rather than men'. ${ }^{65}$ Modern constitutionalism reflects the 'Platonism of modern natural law', the Constitution becomes the new God to worship or the new myth to behold, and the revolutionary treasure of political freedom is lost in the constitutionally frozen republic.

And yet the insight that Arendt's work on revolution brings to bear is that this reflects a problem 'inherent' in the traditional conception of law. ${ }^{66}$ The legacy bestowed by the tradition was an image of law based on command by a superior and obedience by a subject, Hebrew in origin, and represented by the Divine Commandments of the Decalogue. ${ }^{67}$ 'Only to the extent that we understand by law a commandment by which men owe obedience regardless of their consent and mutual agreements,' Arendt argues, 'does the law require a transcendent source of authority for its validity, that is, an origin which must be beyond human power.' 68

\footnotetext{
63 ibid, 184.

64 ibid, 192. 'The authority of self-evident truth may be less powerful than the authority of an "avenging God", but it certainly still bears clear signs of divine origin; such truths are, as Jefferson wrote in the original draft of the Declaration of Independence, "sacred and undeniable".' ibid, 194.

65 Kant was famously ambiguous about the course of the French Revolution, maintaining a preference for the republican over the democratic form of government (democracy for Kant is despotism), because only with the former the ruler 'will reflect that he has taken over an office which is too great for a human being, namely that of administering God's most sacred institution of earth, the rights of man'. In H. Reiss (ed), Kant's Political Writings (Cambridge: CUP, 1991), 103. Although beginning from the moral principle of autonomy, the realities of the political realm are of a republican sovereign determining the general will on our behalf. Kant is ultimately unable to believe in democratic constitution-making because of his faith that 'we ought to obey God rather than men'. fn 1, 31. The central conviction of constitutionalism, Friedrich later argues, has a religious foundation; it reflects the notion of 'a divine justice that transcends the human understanding'. C.J. Friedrich, Philosophy of Law in a Historical Perspective (Chicago: Chicago University Press, 1958), 19.

66 Arendt, n 2 above, 195. Only Montesquieu manages to break from the ‘tradition' of legal absolutism; see below.

67 ibid, 189

68 ibid.
} 
Because of the apparent 'arbitrariness' of the new beginning - after the revolutionary hiatus between a 'no-longer' and a 'not yet' - it seemed natural to seek for 'an absolute' as a foundation for the new republic. The problem of the beginning, notes Arendt, 'appears first in thought and speculation about the origin of the universe', and the Hebrew solution for its perplexities was 'the assumption of a Creator God who is outside his own creation in the same way as the fabricator is outside the fabricated object'. ${ }^{69}$ The notion of the Sovereign being at the origin and outside of the 'fabricated' (or positive) law survives in Austin's theory of law as the command of the sovereign and reaches its apogee in Carl Schmitt's theory of the Sovereign as he who decides on the exception. ${ }^{70}$

This imperative view of law is built upon the tradition's fundamental misconception of freedom as the arbitrary exercise of individual will. With the association of law as a command of the will - the very essence of the 'will' is to command and be obeyed, Arendt notes, - the notion of sovereignty continues to dominate our modern juristic imagination, whether it is the sovereignty of the ruler (as in the ideology of 'popular sovereignty') or the sovereignty of a rule or set of rules (as in the expression the 'sovereignty of the constitution'). According to Arendt, this notion of sovereignty and its accompanying conception of rule are designed to avoid the uncertainties of political action in the conditions of human plurality. They mark the desire to escape from politics, and therefore from freedom, altogether. The 'hallmark' of all such escapes from politics is, says Arendt, 'the concept of rule', because it implies 'that men can lawfully and politically live together only when some are entitled to command and others forced to obey. ${ }^{71}$ The commonplace notion that political community is necessarily constituted in this dualistic fashion rests on a suspicion of action and the wish for it to be displaced.

From a juridical perspective, the persistence of the 'absolute' is linked to the image of man as homo faber, in the sense of being a law - or constitution-maker, because it is a reflection of the theological image of 'God the creator'. Rules are 'fabricated' in advance in accordance with a preconceived 'idea' (the result of 'contemplation') and in order to present firm boundaries to political action and limit the contingencies of human affairs. ${ }^{72}$ Once a substitute for action is found, politics then becomes mere administrative execution, analogous to the private economic decisions of the household, a substitution that, we will now see, is not distinctively modern, but takes its cue from the Platonic inauguration of the 'great

\footnotetext{
${ }^{69}$ ibid, 206

${ }^{70}$ For Schmitt, the sovereign decision is an 'absolute beginning', because it springs from normative nothingness and a concrete disorder'. A. Kalyvas, 'Who's Afraid of Carl Schmitt?' (1999) 25(5) Philosophy and Social Criticism 87, 97. Kalyvas explains that the idea of a creation ex nibilo is a legacy of Schmitt's political theology, the analogy is the divine power which can create an order to which it is not itself subject just as the constitution cannot absorb the constituent subject, the people. See A. Kalyvas 'Carl Schmitt and the Three Moments of Democracy' (2000) 21 Cardozo Law Review 1542.

71 Arendt, n 10 above, 222.

72 ibid.
} 
tradition'. That the essential characteristic of all authoritarian government is a source of authority 'beyond the sphere of power' and, like the law of nature or the commands of God, not itself 'man-made,' goes right back to Plato's political philosophy. ${ }^{77}$

\section{THE LIBERATION OF THE TRADITION: THE EMERGENCE OF HOMO FABER FROM MODERN REVOLUTION}

In modern terms, it is said, 'constitution' actually means the 'active making of a new order, as opposed to its gradual emergence in the course of a continual historical development'; it involves 'the idea of an authority and an author whose willpower is the ultimate cause of the polity. ${ }^{74}$ So the modern mind was not only unable to escape the traditional conception of law; it strengthened the prejudice against political action by idolising constitution-making or constitutional authorship (as well as by turning towards a Darwinian assessment of domination as an aspect of our supposedly 'natural' instincts of command and obedience). ${ }^{75}$

In some respects, it is no surprise that fabrication rather than action, constitution-making rather than political freedom, comes to dominate the juridical imagination. The idea emerges in modernity that even newness itself can be 'manmade', with the revolutionary beginnings of the autonomy of the political coinciding with the emerging consciousness that man can make his own bistory. ${ }^{76} \mathrm{It}$ is then a short step to conceiving man's ability to make his own laws, a precursor, in later modernity, and even more spectacularly, as Arendt puts it, to his ability to make 'nature', culminating with his potential escape from the physical and socialpsychological confines of the earth itself. ${ }^{77}$

Constitution-making becomes something of an obsession in modernity, with the commonplace metaphor that constitution-makers are the 'architects' of a prepolitical artifice, making constitutions like 'puddings to a recipe'. The escape from politics suggested by the traditional conception of law as command is thus

\footnotetext{
73 Arendt, $\mathrm{n} 3$ above, 110 .

${ }^{74}$ U. Preuss, 'Constitutional Power-Making for the New Polity: Some Deliberations on the Relations Between the Constituent Power and the Constitution' (1993) 14 Cardozo Law Review 639.

75 Arendt's critique of fabrication extends to authorship. 'Neither the individual life story nor the mundane social reality of historical events have an identifiable author, action being entangled in the web of human relationships. Real stories, in distinction from those we invent, have no author.' Arendt, n 10 above, 185.

${ }^{76}$ Loughlin connects this process to the birth of modern public law: 'The era of religion thus comes to a close only when law is acknowledged to be a human construct, devised by humans according to their own self-defined purposes. Only under conditions of secularisation and positivisation is the medieval idea of fundamental law transformed into the modern discipline of public law.' n 5 above, 7.

77 The Human Condition, n 10 above, begins with the space race, the 'first step towards escape from men's imprisonment to the earth'. 1. According to Arendt, it is Hobbes who introduces the new concepts of 'making' into political philosophy, evident in his metaphor of that 'artificial man' who is the 'Great Leviathan'. ibid, 300.
} 
accompanied by the rise of homo faber 'from the great revolution of modernity', the burden of the tradition compounded with the anti-political substitution of making for acting. This paradigmatically modern notion of constitutional design has come under sustained attack by those for whom it represents the top-down imposition of a planned order rather than the recognition of the customs or conventions of a relatively homogenous community that evolves gradually through time. ${ }^{78}$

And yet Arendt's critique of constitution-making depends not upon any relatively homogeneous community or communal identity, but, conversely, upon the plurality of men that characterises the human condition. For Arendt, to state it bluntly, making is not equivalent to acting, and fabrication does not amount to the exercise of political freedom. On the contrary, the rise of homo faber takes place at the expense of political freedom; it is because of the fundamental condition of plurality on which politics is based that homo faber, implying the idea of one man making something out of other men, is an anti-political category. And Arendt's critique is radical because she deems the idealisation of fabrication to have been set implicitly in motion by the Platonic inauguration of the great tradition, and only liberated, but not fundamentally transformed, by the modern worldview.

So although modern constitutionalism is in danger of suppressing political action, 'the modern age $[\ldots]$ was not the first to denounce the idle uselessness of action and speech in particular and of politics in general'. Exasperation with political action - its unpredictability, irreversibility, and anonymity - is in fact 'almost as old as recorded history'.79 It reflects Plato's foundational hierarchy of the vita contemplativa over the vita activa - the priority of philosophy over politics, ${ }^{80} \mathrm{a}$ story which begins with the Platonic identification of the division between thought and action 'with the gulf that separates rulers from those over whom they rule'. Although the basis for this separation is the experience of the household and the master-slave relationship, ${ }^{81}$ it plays 'its most decisive part in the organisation of public matters' and becomes intimately connected with our understanding of politics. ${ }^{82}$ In the master-slave relationship, there is a clear separation between

\footnotetext{
${ }^{78}$ Charles Taylor, for example, expresses this criticism in his work on Hegel: 'The idea of just designing a constitution and then putting it into practice is an Enlightenment idea. It treats the whole affair as an engineering problem, an external matter of means and design. But a constitution requires certain conditions in men's identity, how they understand self; and hence this enlightenment idea is radically shallow. To try in philosophy to transcend one's age is like trying to jump over Rhodes.' Hegel (Cambridge: CUP, 1975), 421.

${ }^{79}$ Arendt, n 10 above, 220. Italics added. The difference between action and fabrication is given explicit articulation by Aristotle in his Nichomachian ethics: 'doing and making are generically different, since making aims at an end distinct from the act of making, whereas in doing the end cannot be other than the act itself: doing well is itself the end'. Quoted in J. Taminaux, 'Athens and Rome' in D. Villa (ed), Cambridge Companion to Hannah Arendt (Cambridge: CUP, 2000), 168.

80 The hierarchy of action over fabrication 'had in fact, though not expressly already been overruled in the beginnings of political philosophy by the philosophers' deep-rooted suspicion of politics in general and action in particular'. Arendt continues by arguing that for Plato there is an 'inner affinity' between contemplation and fabrication, theoria and poiesis. Arendt, n 10 above, 301.

81 ibid, 223 .

82 ibid, 224.
} 
contemplation and action: 'he who knows does not have to do and he who does needs no thought or knowledge. ${ }^{83}$ And as the philosopher-king commands the city, Arendt notes, 'the soul commands the body and reason commands the passions'. ${ }^{84}$

This identification of knowledge with command and rule and of action with mere obedience and execution was so powerful that it not only 'overruled all earlier articulations in the political realm', it also 'became authoritative for the whole tradition of political thought'. ${ }^{85}$ The domination of rulership over action was attained and given extended longevity because of the interpretation of 'rule' in terms of fabrication. Even the key word of Plato's philosophy, 'idea', is taken from experiences in the realm of fabrication, from the division between the perception of an image of the 'product-to-be' and the 'means' of making it. According to the parable of the cave, it is only in returning to the shadowy company of his fellow men that the philosopher needs 'the idea' - the true essence of being - for guidance, to act as a standard or rule 'by which to measure $[\ldots]$ the varied multitude of human deeds and words with the same absolute, "objective" certainty with which the craftsman can be guided in making. ${ }^{86}$

Since Plato's analogies of household life and the private sphere, such as master-slave or shepherd-flock, would, when applied to the public sphere, suggest the quasi-divine quality of rulership (to distinguish the ruler 'as sharply from his subjects as the slaves are distinguished from the master or the sheep from the shepherd'), Plato instead constructs the public space in the image of a fabricated object, which 'carried with it only the implication of ordinary mastership'. ${ }^{87}$ With this image, the concept of the 'expert' enters the realm of political action for the first time, and the competence of the statesman in human affairs is understood in the same sense as that of the 'carpenter to make furniture or the physician to heal the sick'. 88

The substitution of acting for making and the concomitant degradation of politics into a means to obtain a 'higher' end, whether the safety of the philosopher, the salvation of souls, or the modern belief in the 'progress' of society, is therefore as old as the 'great tradition' of philosophy. ${ }^{89}$ Although only the modern worldview defined man as homo faber and finally overcame the suspicion of fabrication, this did not constitute a reversal but rather a liberation from prejudices which had prevented the tradition 'from openly declaring that the

83 ibid, 223

84 ibid, 224.

85 ibid, 225.

86 ibid, 226.

87 ibid, 227. The analogy of the 'idea' that the craftsman has, visualised by his 'inner eye' and which transcends the product and lies 'beyond the fabrication process it guides' suggests that there are ideal standards for failure or success. "The ideas become the unwavering "absolute" standards for political and moral behaviour and judgment in the same sense that the "idea" of a bed in general is the standard for making and judging the fitness of all particular manufactured beds.' Arendt, $\mathrm{n} 3$ above, 110).

88 Arendt, $\mathrm{n} 3$ above, 111.

89 Arendt, n 10 above, 229. 
work of the craftsman should rank higher than the 'idle' opinions and actions that constitute the public realm'. ${ }^{90}$

This displacement of action is associated by Arendt 'with the whole body of argument against democracy', and, she continues, it is ultimately an argument against the essentials of politics itself because it tramples over the human condition of plurality, 'the condition sine qua non for that space of appearance which is the public realm'. ${ }^{91}$ The attempt to do away with this plurality, whether through monarchy, tyranny, the benevolent Platonic philosopher-king, or those forms of democracy that assume the body politic to constitute an unproblematic unity, 'is always tantamount to the abolition of the public realm', banishing the citizen to the private sphere of personal and material interests. In the Platonic Republic, Arendt notes, 'the philosopher-king applies the ideas as the craftsman applies his rules and standards; he "makes" his City as the sculptor makes a statue; and in the final Platonic work these same ideas have even become laws which need only be executed'. ${ }^{2}$ Politics then becomes about mastering the techniques of human affairs according to a predetermined plan, based on a constitutional blueprint for a utopia. In the modern age, this is reflected in our valuing the work of the politician as a technician or craftsman, rather than the opinions of those acting and speaking with each other in the public realm. ${ }^{93}$

\section{CONCEPTUALISING LAW BEYOND 'THE TRADITION': NOMOS OR LEX?}

Was there any alternative to the traditional conception of law, which assumed rulers and ruled, sovereign and subject, and an absolute source of authority and which retained such a tight grip on the modern juridical consciousness? Was there any alternative to the idealisation of the constitution-maker as homo faber at the expense of genuine political action and freedom? Arendt insists that there were other juridical traditions and experiences on which the revolutionary imagination could have drawn:

When the Athenian city-state called its constitution an isonomy, or the Romans spoke of the civitas as their form of government, they had in mind a concept of power and law whose essence did not rely on the command-

\footnotetext{
${ }^{90}$ Plato and, albeit to a lesser degree, Aristotle, who deemed craftsmen not even worthy of full citizenship status, nevertheless 'were the first to propose handling political matters and ruling political bodies in the mode of fabrication'. ibid, 230.

91 ibid, 220.

92 ibid, 227.

$93 \mathrm{ibid}, 229$. This turns the evaluation of law and politics into an assessment of means and ends and it therefore prefigures the domination of instrumental rationality that Max Weber documented.
} 
obedience relationship and which did not identify power and rule or law and command. ${ }^{94}$

Although the revolutionaries of the late 18th century did partly turn to antiquity in attempting to construct a new republic that would rest on the principle of the consent of the governed, they were ultimately unable to escape the shackles of the tradition. They overlooked the potential of two alternative conceptions of law, the Greek nomos and the Roman lex, both of which could have mitigated the burden of the tradition and its problem of the absolute, which 'neither Roman nor Greek antiquity was ever perplexed by'. ${ }^{5}$ Neither the Greek nomos nor the Roman lex was of divine origin, and neither the Greek nor the Roman concept of legislation needed divine inspiration or a legislator who was outside of and above his own laws. Although it was true that the Greeks thought the lawgiver could be a stranger called from abroad, 'this meant no more than that the laying down of the law was pre-political [...] just as building the walls around the city was prior to the coming into existence of the city itself. ${ }^{96}$ The very word, nomos, which 'received its full meaning as the opposite of $[\ldots]$ things that are natural', stresses the "artificial", conventional and man-made nature of the law'. ${ }^{97}$ Although the Roman lex was in an important sense different from Greek nomos, neither lex nor nomos required a transcendent source of authority.

The metaphor of 'building the walls around the city' of course recalls the modern category of constitution-making and signals an important difference between the twin conceptions of antiquity, which Arendt only hints at in her analysis of their influence on the men of the 18th century revolutions. In examining the contrast, rather than the similarity, between these two conceptions, the Roman lex suggests a path beyond the tradition, albeit one which was not ultimately followed, whilst the Greek nomos reveals the pitfalls characteristic of the category of fabrication and the idealisation of homo faber. ${ }^{98}$

The Roman lex, construed by Arendt as meaning 'lasting tie' and eventually 'contract', can be understood as linking human beings together through mutual

\footnotetext{
94 Arendt, n 47 above, 40.

95 Arendt insists that John Adams was wrong in claiming that 'the general opinion of ancient nations' was that 'the Divinity alone was adequate to the important office of giving laws to men'. n 2 above, 186.

96 ibid.

97 ibid.

${ }^{98}$ In the posthumously published 'Introduction into Politics', Arendt presents the contrast between nomos and lex in a stark fashion. The contrast is introduced after a discussion of the political significance of the Trojan war of annihilation, significant not only because of the threat of a contemporary war of annihilation in the wake of the Second World War and the bombing of Hiroshima, but because in interrogating 'the solution to the question of war' Arendt reflects, 'we might discover the origin of the concept of law'. For the Greeks, the 'grand impartiality' of Homer's account of the Trojan war suggested the complete exclusion of war and the brute force it entailed 'from what was truly political', namely that which arose between and belonged to the citizens of the polis. To the Greek way of thinking, she adds, 'freedom was rooted in place, bound to one spot and limited in its dimensions and the limits of freedom's space were congruent with the walls of the city, of the polis, or, more precisely, the agora contained within it'. The Promise of Politics, n 11 above, 170.
} 
agreements, ${ }^{99}$ and hence through the faculty of promising, which Arendt gives great weight to in 'The Human Condition', and claims to have influenced the American (as opposed to the French) revolutionaries via the writings of Montesquieu. The great variety of contract theories which Roman lex gave birth to 'attests to the fact that the power of making promises has occupied the center of political thought over the centuries'. 100 We will return to the faculty of promising as central to political action in our concluding remarks, but it is important to note that this potential is one that is revealed uniquely through the Roman lex, because although the Greeks, like the Romans, tied law to the activity of speech that was central to all politics, only for the Romans did legislative activity, and the laws themselves, belong to the realm of politics. For the Greeks, on the other hand, 'the legislator's activity was so radically disconnected from the truly political activities and affairs of the citizens within the polis that the law-giver did not even have to be a citizen of the city'. On the contrary, he could be engaged from outside to perform his task, Arendt continues, 'much like a sculptor or architect commissioned to supply what the city required'. 101

Since the Greek concept of nomos is pre-political, it is associated, like the activities of Plato's philosopher-king and modern constitution makers, with an isolated and even singular task of contemplation that is followed, like the work of 'sculpture' or 'architecture', by a process of fabrication in accordance with a preconceived plan:

For the Greeks, law [...] is essentially conceived by a law-giver and must first exist before it can ever enter into the political realm. As such it is prepolitical, but in the sense that it is constitutive for all further political action and interaction. Just as the walls of the city [...] must first be built before there can be a city identifiable by its shape and borders, the law determines the character of its inhabitants [...] The law is a city wall that is instituted and erected by one man, inside of which is created the political realm where many men move about freely. ${ }^{102}$

There can be little doubt that Arendt reconstructs this conception of law in order to challenge it. ${ }^{103}$ If reconstructed in the manner of nomos, law is associated with precisely those aspects of the human condition that are not merely pre-political

\footnotetext{
99 ibid, 179.

${ }^{100}$ Arendt, $\mathrm{n} 10$ above, 244.

101 Arendt, The Promise of Politics, n 11 above, 179.

102 ibid, 180. See also Arendt, n 2 above, 186-187. Also in Arendt, n 10 above, 194: For the Greeks already, 'the law-maker was like the builder of the city wall, someone who had to do and finish his work before political activity could begin' and was therefore to be treated 'like any other craftsman or architect'. 103 More than once, Arendt expresses her allegiance to the Roman notion of lex. After the passage just cited, Arendt speaks of the Roman conception as 'extraordinarily fruitful'. The Promise of Politics, n 11 above, 180. In Arendt, n 10 above, she speaks of the 'true genius' of Rome, and in $\mathrm{n} 2$ above, the 'great Roman model'. 199. On the influence of Roman thought in Arendt, see D. Hammer 'Hannah Arendt and Roman Political Thought' (2002) 30(1) Political Theory 124.
} 
but in an important sense anti-political: violence, singularity, and fabrication as opposed to power, plurality, and action. The crucial point, Arendt stresses, is that the law in terms of nomos has something violent about it because it comes into being 'by means of production, not of action'. The lawgiver in Greece 'resembles the architect of the city and its builder, not the politikos and citizen'. ${ }^{104}$ This conception of law as an aspect of the human artifice is echoed by modern man's conviction that he 'can know only what he makes' and that he is therefore primarily homo faber rather than animal rationale. But the apparent necessity and in some cases glorification of violence that was particularly striking in the series of modern revolutions, Arendt notes, comes with the important 'exception of the American' revolution. ${ }^{105}$

The 'singularity' inherent in the category of fabrication and characteristic of the Greek conception of law-making did, nevertheless, still have a telling influence on the US founders. ${ }^{106}$ The Platonic understanding of rule, through which 'the many become one in every respect', is of course reflected in the American founding motto, e pluribus unum. It was fear of plurality and of the unpredictability and spontaneity of political action (the entanglement in a complex web of human relationships that it entails) which had inspired the Greeks to set limits by means of nomos and 'to interpret the law not as a link and a relationship, but rather as an enclosing border than no one should overstep', 107 just as a similar fear might be thought to underline Madison's concern as expressed in Federalist Number 10 to guard against political factions.

This assumption that the purpose of constitutional law is to place limits on political action is ultimately tied up with the same erroneous and reductive conception of politics and of freedom that plagued the traditional conception of law as command. So although the Greek conception of nomos does not fall prey to the absolutism of the Hebrew-Christian tradition, it does, like command, ultimately reflect the same attempt to escape from political freedom, where freedom is understood as the ability 'to call something into being that did not exist before', to bring something new into the world in concert with others and in the context of plurality. The upshot of nomos is that freedom is secured by ensuring restraints, even if these are understood in modern constitutional language as 'enabling restraints'; in both cases freedom is that which remains after the city wall has been

\footnotetext{
104 Arendt, The Promise of Politics, n 11 above, 181. For Arendt, the architectural metaphor of fabrication always suggests a certain violence; without the violence of the maker, 'no fabrication could ever come to pass'. n 10 above, 228. See also Arendt, The Promise of Politics, n 11 above, 111.

105 Arendt, n 10 above, 228. Although misleading as a broader historical point, this is conceptually significant in that it suggests not only that violence is distinguishable from power but also that it is avoidable in constitutional politics. See also Arendt, $\mathrm{n} 3$ above, 140.

106 Madison, for example, noted that the task of framing the constitution of government has in history 'been performed by some individual citizen of pre-eminent wisdom'. In Federalist, no 38, quoted by Arendt, n 2 above, 312. The revolutionaries on both sides of the Atlantic were influenced by the Machiavellian idea that, 'to found a new republic must be the work of one man only'. ibid, 207. Contributing to the failure of the French case was Robespierre's self-perception as the 'architect' who will build out of 'human material a new house for human beings'. ibid, 208.

107 Arendt, The Promise of Politics, $\mathrm{n} 11$ above, 186.
} 
built. As in the 'housing' metaphor that Arendt herself employs, freedom is left to 'dwell' after the house has been constructed rather than exercised in the construction (and reconstruction) of the house itself. If freedom is left merely to 'dwell', it might not be long before it dissipates altogether.

The basic error of the tradition, Arendt notes, lies in its identification of freedom with sovereignty, something that 'has always been taken for granted in political as well as philosophic thought'. ${ }^{108}$ But 'no man', Arendt admonishes, 'can be sovereign because not one man, but men, inhabit the earth'; 109 sovereignty as an idea simply makes no sense in the human condition of plurality. The notion that constitutional law is a pre-political construction, presenting a space that 'houses' (by regulating and limiting) freedom qua personal sovereignty is therefore paradoxically a mirror image of the erroneous conception of law as command. It is the wholesale rejection of freedom as personal sovereignty - freedom from undue interference by others - that suggests the alternative conception of freedom to constitute and reconstitute our basic laws. This constitutional potentia suggests not only that political freedom is experienced as the exercise of power in common with others but also that law and politics are thoroughly and foundationally intertwined.

And yet, ironically, although the founders of the American republic could not escape the tradition and fulfil this potentia, they had stumbled on the answer to the vicious circle of law's foundations. The act of engaging with one another through promises and mutual ties, reminiscent of the Roman lex, and which constituted the 'new beginning' of the republic, carries its own principle with it. It had, moreover, in Montesquieu and his theory of the separation of powers, the only philosopher of the Enlightenment who consistently avoided the absolute and the basic conflation of freedom and sovereign will.

[A]mong the pre-revolutionary theorists only Montesquieu never thought it necessary to introduce an absolute $[. .$.$] into the political realm. This is closely$ connected with the fact that $[. .$.$] only Montesquieu ever used the word 'law'$ in its strictly Roman sense [...] as the relation subsisting between different entities [...] Neither religious nor natural laws, therefore, constitute for Montesquieu a 'higher law', strictly speaking [...] And since, for Montesquieu, as for the Romans, a law is merely what relates two things and therefore is relative by definition, he needed no absolute source of authority and could describes the 'spirit of the laws' without ever posing the troublesome question of their absolute validity. ${ }^{110}$

\footnotetext{
108 Arendt, n 10 above, 234.

109 ibid.

110 Arendt, n 2 above, 188-189.
} 
The contrast with Rousseau is telling. ${ }^{111}$ Rousseau's 'General Will' is still God-like; it is "still a divine Will which needs only to will in order to produce a "law". ${ }^{112}$ His substitution, as Arendt sees it, of consent and opinion with this category of the 'will', 'essentially excludes all processes of exchange of opinions and an eventual agreement between them'. ${ }^{113}$ For Arendt this speaks of a complete absence of freedom: the difference is fundamental, for Arendt, as explained in her critique of 'the tradition', freedom dwells in the 'We can', not the 'I will' (or even the 'We Will'). Freedom is experienced as the capacity to perform the infinitely improbable', to act in concert with others in the public realm and to bring something new into the world. It is expressed politically through the 'framework of ties and bonds, such as laws and constitutions', which ultimately derive their legitimacy 'from the faculty of promising with one another in the face of the essential uncertainties of the future'.114

\section{CONCLUDING REMARKS: RECONCILING POLITICAL FREEDOM AND CONSTITUTIONAL AUTHORITY?}

Does the image of law as lex therefore suggest an alternative path towards the reconciliation of political freedom and law, so that we need not confront constitutionalism as presenting a fateful ambivalence between them? To be sure, lex avoids the image of fabrication and its concomitant suppression of political freedom, with its suggestion, as Jeremy Waldron has recently reminded us, of the singularity of the constitutional framer - one man making something out of other men. It presents instead an image of constitutionalism as political freedom, 'as an activity that arises among men acting and speaking together'. ${ }^{115}$ An exploration of this image will invite further reflection on the tension between the authority of the constitution and democratic political freedom. ${ }^{116}$

\footnotetext{
111 'J]ust as Montesquieu's theory of the separation of powers had become axiomatic for American political thought $[\ldots]$, so Rousseau's notion of a General Will [...] became axiomatic for all factions and parties of the French revolution, because it was indeed the theoretical substitute for the sovereign will of an absolute monarch.' ibid, 155.

112 ibid, 183.

113 ibid, 76. She continues by criticizing the inherent instability of the General Will, most evident in Robespierre's revolutionary appropriation of Rousseau's idea, but which Rousseau himself concedes with his famous line, 'il est absurde que la volonte se donne des chaines pour l'avenir. As such the general will is built, like Robbespierre's pouvoir constituant, on 'quicksand'. The very idea of a unity of wills upon which Rousseau relies, Arendt says, comes from the basic proposition that two antagonistic wills are united in the presence of a third that opposes them both, and thus leads to the presupposition of a common national enemy (and of course show us the relatively direct route towards Carl Schmitt). ibid, 78.

114 Arendt, $\mathrm{n} 3$ above, 162.

115 J. Waldron, 'Arendt's Constitutional Politics' in Villa, n 79 above, 204.

${ }_{116}$ On the relationship between democracy and the political in Arendt's work, see S. Wolin, n 52 above. He suggests that the 'antidemocratic strain', most evident in Arendt's earlier work, is tempered in her later writings as a result of her political experiences in the 1960 s.
} 
The constitutive activity suggested by lex is conducive to political freedom because it is about calling forth something intangible and improbable through the joint exercise of power, the mutual pledges and collective acts of promising, on the basic principle of pacta sunt servanda. So the tragic irony of the lost revolutionary tradition in the US is, for Arendt, that the Founders had actually stumbled across the method of avoiding the descent into the absolutism of the tradition, through the mutual promises and covenants based in the reciprocal trust of the early settlers: this foretold the creation of the political beginning which was to be the new republic. The act of foundation could operate as a 'fountain of authority', just as the word constitution carries a twofold meaning; it is both the act of constituting and the result of what is constituted:

The very fact that the men of the American revolution thought of themselves as founders indicated the extent to which they must have known that it would be the act of foundation itself, rather than an Immortal Legislator $[\ldots]$ or self-evident truth or any other transcendent $[\ldots]$ source, which eventually would become the fountain of authority in the new body politic [...] It is futile to search for an absolute to break the vicious circle in which all beginning is inevitably caught, because this absolute lies in the very act of beginning itself. ${ }^{117}$

The vicious circle of the legality of the new law and the legitimacy of the new power is tamed not by positing an absolute, but by developing a principle from the act of beginning, which, Arendt notes, for the first time in history occurs in the US 'in broad daylight'.118 This event, breaking into the continuous sequence of historical time, manifests the constitutional potentia and reveals the possibility of political freedom without the absolutism of a creatio ex nibilo. What saves the act of beginning from arbitrariness 'is that it carries its own principle with itself, or to be more precise, that beginning and principle are not only related to each other but are coeval'.119 The political relevance of these insights, Arendt argues, is that they stand in opposition to the claim that violence is necessary for all foundations and unavoidable in all revolutions, a claim that she (misleadingly) suggests is refuted by the American revolutionary experience. ${ }^{120}$ What the experience does genuinely point to is the possibility of a distinction between the beginning as 'absolute' - as in the case of fabrication in accordance with a fixed ideal - and the beginning as a 'principle' of joint political action, which is always dynamic, temporal, and contingent:

\footnotetext{
117 Arendt, n 2 above, 205.

118 When the element of 'beginning', which was initially co-joined with the entitlement to rule, disappeared from the concept of rulership, 'the most elementary and authentic understanding of human freedom disappeared from philosophy'. Arendt, n 10 above, 224-225.

119 Arendt, $\mathrm{n} 2$ above, 213.

120 Arendt, n 10 above, 228. Arendt's claim is historically dubious, but still conceptually relevant.
} 
[A] terminological distinction between the word 'principium' (beginning of the world) and 'initium' (the beginning which is a man), underlin[es] that, by contrast with the absolute beginning (principium) that can only be the work of God, the human beginning (initium) is always inserted within the continuum of time and thus necessarily amounts to a re-beginning. ${ }^{121}$

And yet what is distinctive about the escape from tradition is not only the novelty and exhilaration of political freedom but the fact that the revolutionary events 'concern the many and not the few'. ${ }^{22}$ In this sense, modern revolution is not only about freedom but also about equality as a 'birthright', which 'was utterly unknown prior to the modern age'. ${ }^{123}$ Newness, as Arendt puts it, 'reaches the market place' in the wake of modern revolution. ${ }^{124}$ It is, in other words, although Arendt fails to develop the point, the birth (or rebirth) of democratic political freedom that is signalled by the late eighteenth century revolutions. Constitutional potentia must be understood as a democratic potentia if it is to remain faithful to the promise of modernity.

Although the revolutionaries still, unhappily, talked about 'obedience' to law, because of their inability to transcend the tradition, what they meant, according to Arendt, was rather the support of the laws through the consent of the citizen. This understanding of power based on consent recalls another aspect of Arendt's distinction between power and violence. Whereas violence can manage without the many, power always stands in need of numbers. ${ }^{125}$ After the modern democratic revolutions, constitutionalism must therefore stand against the Platonic understanding of it as that part of theology which 'taught the few how to rule the many', as well the liberal understanding of it as a 'counter-majoritarian' device based on the 'fear of the many'. It should instead approximate to the Greek isonomy (the notion of 'no-rule'), which conceives equality not on any naturalistic basis or self-evident truths, but in virtue of the social and political equality of citizenship. ${ }^{126}$

But how can 'the many' act in concert when it comes to constitutional politics? Or, to reverse the question, how can mere 'consent' be sufficient for the

\footnotetext{
121 S. Delacroix, 'Schmitt on Kelsenian Normativism' (2005) 18(1) Ratio Juris 40, n 25, paraphrasing from H. Arendt, The Human Condition (Chicago: University of Chicago Press, 1998), 177 n 3.

122 See Arendt, n 2 above, 39.

$123 \mathrm{ibid}, 40$. She continues, 'Liberation in the revolutionary sense came to mean [...] that all those who always lived in darkness and subjection to whatever powers there were, should rise and become the supreme sovereign of the law.' The problem is that rather than overcoming the concept of sovereignty this suggests that the sovereign had merely been replaced; it was now a popular sovereignty that lay at the foundations of the constitution.

124 ibid, 47.

125 Arendt, n 47 above, 42. 'It's the people's support that lends power to the institutions of a country, and this support is but the continuation of the consent that brought the laws into existence to begin with'. ibid, 41 .

126 Arendt, n 2 above, 30-31. Arendt suggests elsewhere that 'isonomia' is merely the equal right to speak in the polis and that it is a mistake to associate equality with justice, as is the modern inclination. Arendt, The Promise of Politics, $\mathrm{n} 11$ above, 118.
} 
generation of political power and expression of political freedom? The choice we seem to be faced with is the following: Restrict political freedom to the freedomfounding actions of those who actually engage in the constitutive activity associated with lex, thereby rendering freedom elusive and elitist, sporadic and fleeting, or generalise and dilute political freedom and risk that it becomes little more than the pallid acquiescence in the structure of constitutional authority. ${ }^{127} \mathrm{~A}$ similar problem is often reconstructed in constitutional theory with regard to future generations: how are they in practice to re-live the mutual constitution of the body politic, as Jefferson wished, without descending into chaos, as Madison feared?

There is thus a final dilemma, an examination of which brings us closer to the tension between political freedom and law. The lost spirit of revolution seems to be the inevitable result of a paradoxical problem of foundations, since it contains two elements that appear to be irreconcilable: modern constitutionalism must exhibit a concern for both the stability and authority of the new structure and the 'exhilarating awareness of the human capacity of beginning.'.28 Arendt argues persuasively that the institutions of the post-revolutionary era that gave stability to the new polity, the Senate and the Supreme Court, and answered the early preoccupation with permanence and the 'augmentation' of the foundations of the republic, were precisely those same institutions which destroyed the spirit of revolution itself and undermined the possibility of maintaining political freedom in terms of the democratic constitutional potentia of 'we, the people'. But how, if at all, can the political freedom of the many be reconciled with the constitutional authority of the few, without reintroducing a problematic foundationalism of constitutional origins?

Although this is a dilemma that Arendt never directly confronts, she does suggest an analogy that is more apposite to its resolution than that of 'fabrication' (or even of 'promising'). More apt to capture the 'immanence and plurality' of democratic constitutionalism than the metaphor of building, housing, or erecting walls and structures is that of constitutional law as 'political grammar or syntax'. ${ }^{129}$ Rather than suggesting a one-off activity or constitutional moment when the 'house' wherein freedom can dwell is constructed or reconstructed in one go, it suggests a dynamic and on-going narrative in the changing circumstances of plurality, and in which freedom is negotiated and renegotiated in the public realm. Constitutionalism as political grammar represents the idea that even our most fundamental law is relational and dynamic, developing symbiotically with politics and

\footnotetext{
127 In contrast to her assessment of revolutionary political freedom, Arendt suggests that the Greek concept of freedom 'does not require an egalitarian democracy' but rather 'a quite narrowly limited oligarchy or aristocracy'. Arendt, The Promise of Politics, n 11 above, 118. This tension between a revolutionary and an aristocratic sense of freedom is pervasive in Arendt's work.

$128 \mathrm{~J}$. Cohen and A. Arato argue that this problem is due to Arendt's failure to draw on the concept of civil society as a mediator between law and power: See Civil Society and Political Theory (Cambridge, Mass: 1992), eg 193.

${ }^{129}$ Waldron, n 115 above, 204. See Arendt, n 2 above, 175.
} 
the exercise of political freedom rather than being fabricated or constructed 'up front' as a timeless container for the vicissitudes of political action. ${ }^{130}$

130 As Martin Loughlin has put it, 'Public law is neither a code of rules or a set of principles but a practice. Understood as the law relating to the activity of governing, public law can be defined as that assemblage of rules, principles, canons, maxims, customs, usages, and manners that condition, sustain and regulate the activity of governing. These practices comprise conventions and rules of speech - a vocabulary and a syntax - which are being continually developed.' The Idea of Public Law (Oxford: OUP, 2003), 155. 